\title{
INCIDENT OF LEPTOSPIROSIS AMONG CATTLE AND POULTRY WORKERS IN CHENNAI (SOUTH INDIA)
}

\author{
Thiruvengadam $\mathbf{S}^{1}$, Mazher Sulthana ${ }^{2}$, Sumathi $\mathbf{G}^{3}$, Dhandayuthapani $\mathrm{K}^{4}$ \\ ${ }^{1,4}$ Department of Biotechnology, Sree Sastha Institute of Engineering and Technology, Chennai, India \\ ${ }^{2}$ Department of Zoology, The Presidency College, Chennai , India \\ ${ }^{3}$ Department of Microbiology, Chennai Medical College, Chennai , India. \\ E-Mail: thiruvengadam_s @ yahoo.com
}

\begin{abstract}
A serological survey was carried out in suspected cases of leptospirosis with fever, Jaundice, Myalgia, Diarrhoea, Conjunctival hemorrhage etc in cattle and poultry workers. A total 165 serum samples from male and female individual at different age groups were tested including control. The prevalence data were analyzed in relation to age, sex and sero groups. Of the sample $18.7 \%$ reacted with antigens of different sero groups of titer ranging from $1 / 40$ to $1 / 1280$ with predominance of titer less than (or) equal to 1/160; of positive sera reacted with respective of the autumnalis sero group. Reaction with autumnalis (25.8), hebdomalis (22.5), australis (19.3), pomona, (9.6) grippotyphosa (6.5), copenhageni (9.6) and mixed (6.5) were also detected, through at lower frequencies. The true incidence of the diseases is probably much higher here. Male comprised above (24\%) or the cases, the higher rule of infection was in the $20-45$ years age groups. For female incidence increased with age up to late middle - age. The incidence of disease much higher among cattle and poultry workers.
\end{abstract}

KEY WORDS: Leptospirosis, Serology, Serovar, cattle, MAT, MSAT, ELISA

\section{INTRODUCTION}

Leptospirosis is a contemporary zoonosis affecting all warm and even cold blooded vertebrates. It prevailed throughout the world, though higher incidence had been recorded in tropical and subtropical regions where the climatic conditions highly favor the existence of Leptospires. Leptospirosis is known to be endemic in Chennai city and several other places around the Chennai $[1,2]$. This metro politician city surrounded by most polluted Coovam River, rice field and cattle, poultry forms and small rural communities. Chennai has a tropical climate throughout year with temperature ranging from 24$32^{\circ} \mathrm{C}$ and it receives around $1800 \mathrm{~mm}$ rainfall annually. Most of the rainfall is during monsoon season in the month of October to December. This climatic condition is ideal for survival of leptospires, particularly during monsoon when river, rice fields are flooded (or) wet. During this season most of the water bodies are contaminating with sewage and urine of infected and carrier animals. Most of illiterate people those who are working in poultry, Cattle shed, sewage workers and farmers get infection leptospires due to barefoot walking in contaminated water logged areas. Because of these factors, Leptospirosis is a potential health problem of rural communities in around the Chennai city [3].

In Chennai city leptospirosis is account for about $30 \%$ the cases of PUO during the monsoon season. It is also the major cases of renal failure [4]. Although Chennai and surrounded villages are have ideal epidemiological condition for the transmission of Leptospirosis, due to heavy rain flood and water contamination in lost monsoon.
No study on leptospirosis in cattle and poultry has been conducted in this area. We conducted a various hospital and laboratory based study on leptospirosis in poultry and cattle workers with predominant symptoms of fever, Myalgia, conjunctival suffusion, Diarrhea and body pain.

\section{MATERIAL AND METHODS}

165 Blood and Serum Samples were collected from cattle and poultry workers from various places of Chennai by the help of hospitals, physicians and laboratories with predominant symptoms, of fever, headache, myalgia, Diarrhoea, Jaundice, and conjunctival signs etc. The history of patients and case report were recorded. The sample which we have collected from different places were stored and sent to the laboratory of Leptospirosis, Madras Medical College and examined. 6 negative samples also collected from healthy person without clinical sign for reference and comparison.

Isolations of Leptospirae: This was attempted in some suspected cases, with freshly collected blood sample. A few drops of blood (or) Broken-up blood clot serum sample were inoculated with EMJH [5] medium in the presence of BSA and also incubated at $32^{\circ} \mathrm{C}$ in dark conditions for 10 days. These tubes were intermittently observed for the presence of growth. 


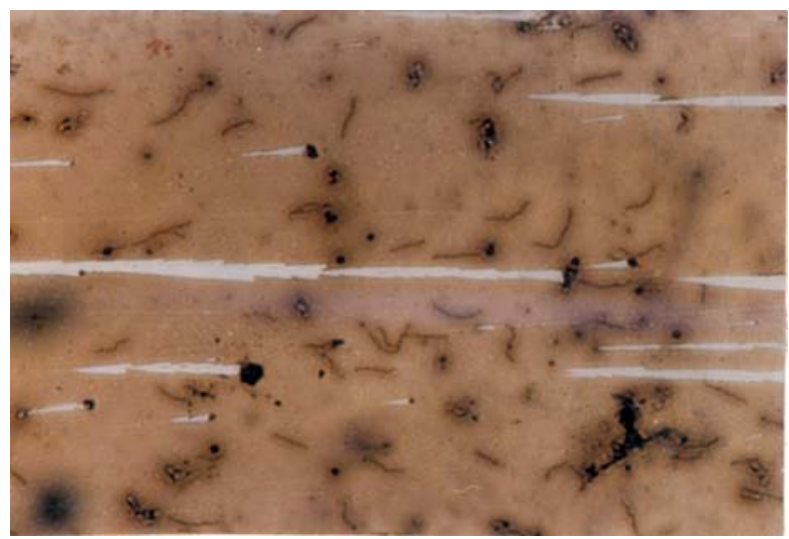

Fig. 1. Brownish black leptospires by Fontana staining

Identification of Leptospirae: Leptospirae in blood, plasma, and culture were identified on the basis of their typical morphology and motility. Examinations were conducted on a minute drop, approximately 101 , which is dispersed in a thin layer between a glass slide and cover slip. Slides were first scanned under low magnification and then at high magnification, for closer observation. Organism grown in culture also stained with Fontana staining and observed.

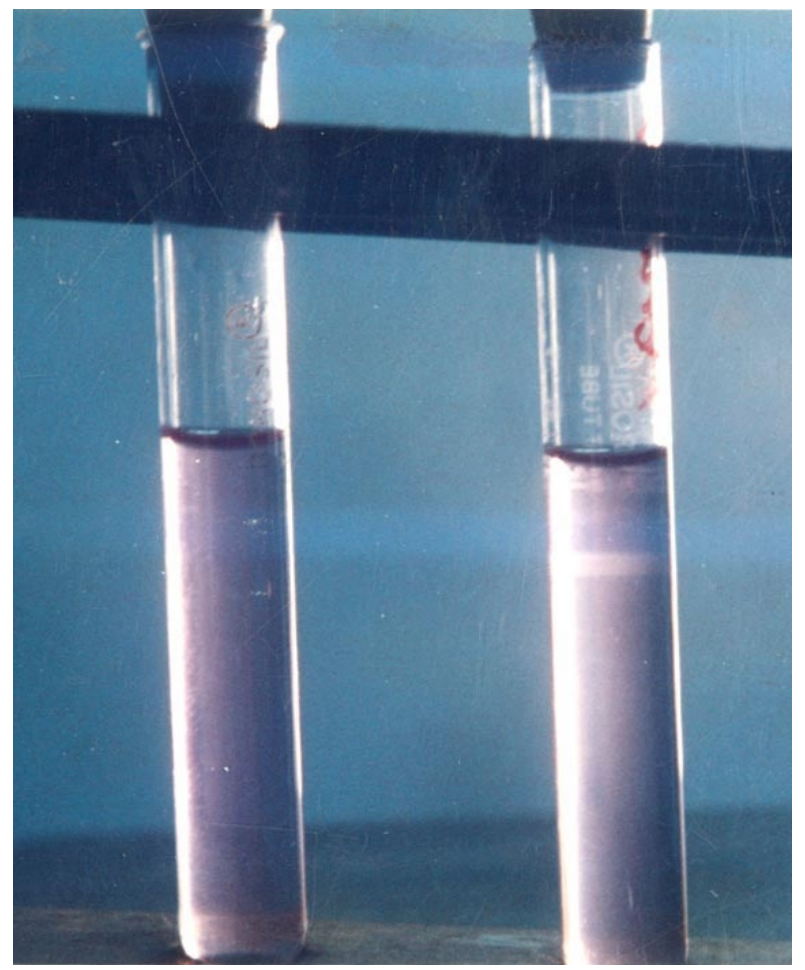

Fig. 2. Growth of Leptospires in EMJH medium with Dinger's ring - disc pattern growth

\section{Methods of Serological tests}

(A) Macroscopic slide agglutinative test: (MSAT). This is a genus specific test with an antigen prepared from patoc -1 strain. It has proved to be a reliable and rapid means of screening for Leptospiral antibodies [6]. Strain patoc -1 is grown in EMJH medium. The strain grows well at room temperature $\left(28{ }^{\circ} \mathrm{C}\right)$, neutralized formaldehyde solution B.P (grade) is added to a fixed dilution of $0.2 \%$ and the Suspension is allowed to stand at room temperature for about $2 \mathrm{hrs}$. It is then centrifuged for $30 \mathrm{~min}$, at $4{ }^{\circ} \mathrm{C}$ to deposit the cells and it's resuspended in phosphate buffed saline (PBS) of Ph 7.2 and again centrifuged at $13,000 \mathrm{rpm}$ for 30 mins at $4{ }^{\circ} \mathrm{C}$. The deposits is resuspended in a little fresh PBS with the aid of a cornwall pipette are pooled in $20 \mathrm{~g}(60 \mathrm{ml})$ medical flat bottle containing a small quantity of sterile glass heads. This is allowed to stand at $4^{\prime} \mathrm{C}$ for 24hrs. Preferably longer during which the content are thoroughly shaken from time to time to ensure an even suspension. The battle is then placed in a beaker containing water and allowed to boil for $30 \mathrm{mins}$. After cooling, the suspension centrifuged at $1000-1500 \mathrm{rpm}$ for 5 mins, to remove any gross particles and clumps and the $\mathrm{pH}$ is adjusted to 7.2. The antigen is stored at $4^{\circ} \mathrm{C}$. For test, one drop of undiluted serum and 1 drop of serum diluted $1 / 10$ with PBS are placed on each of two squares on the glass plate to each drop is added 1 drop of antigen. The serum and antigen drops are carefully mixed with applicator stick, One of which
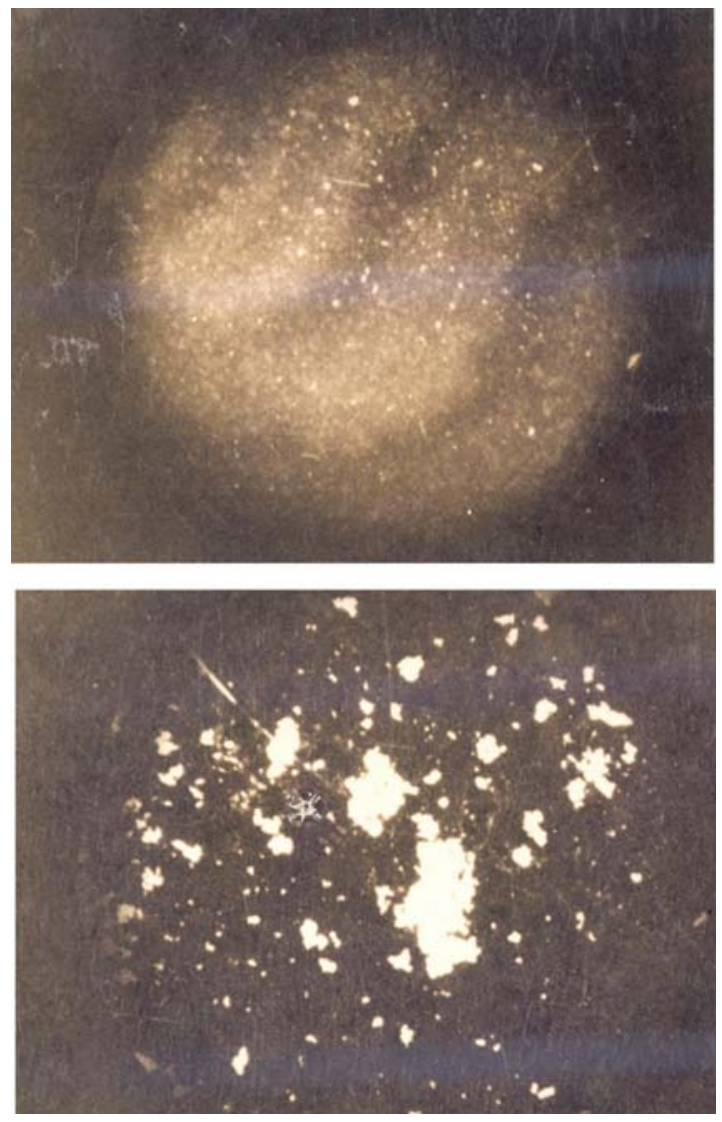

Fig. 3. MSAT 


\section{(a) Clear Suspension - No Clumps}

\section{(b) Test positive: Agglutination of Serum (4+)}

should be a positive and negative control (human serum) can be accommodated on one plate, which is then rotated for 4 mins, at 120rpm. After that agglutination is clearly seen if the pate is held against a dark background. Agglutination is recorded as $4+, 3+, 2+$ and $1+$.

B) Microscopic Agglutination test: The microscopic agglutination test was employed for diagnosis and detects antibodies at Serovar levels. The samples were collected from human including paired serum and plasma sample tested detect the presence of antibody titre. Live antigen required to MAT was obtained from leptospiral reference laboratory, Brisbane, Netherland and West Indies.

The twelve live leptospiral reference strains like australis, autumnalis, ballum, bataviae, canicola, grippotyphosa, hebdomadis, copenhageni, jovanica, Pomona, tarassovi \& patoc were used as antigen, which is obtained from Andaman leptospiral reference laboratory. 57 days old cultures grown in EMJH medium containing approximately 200 leptospires is under each field of low power magnification (20 X objective) of the dark field microscope were used as antigen for the test [7]

The sera were diluted 1:10 in sterile phosphate buffered saline (PBS) pH 7.2 in separate tubes. The test was done in micro agglutination plates. To each well $20 \mathrm{I}$ of the sterile $\mathrm{PBS}<\mathrm{pH} 7.2$ was added by micropipette. To the first well, $20 \mathrm{I}$ of the 1/10 diluted sera was added fold serial dilution were made make the serum dilution as $1 / 20$. Then double fold serial dilution was made by the micropipette. To all the wells, with the help of micropipette, 20ul of the antigen was added after testing for purity and concentration. After the addition of antigen, the dilution of the serum were $1 / 20,1 / 40,1 / 80,1 / 160$ and so on. To promote antigen antibody reaction, the micro agglutination plate was kept at room temperature for 2 hours [8]. Then a drop from each well was taken in a clean a dry slide and examined under low power dark field microscope to read the agglutination reaction, without a cover slip. The agglutination procedure may be done with live antigens [9] .

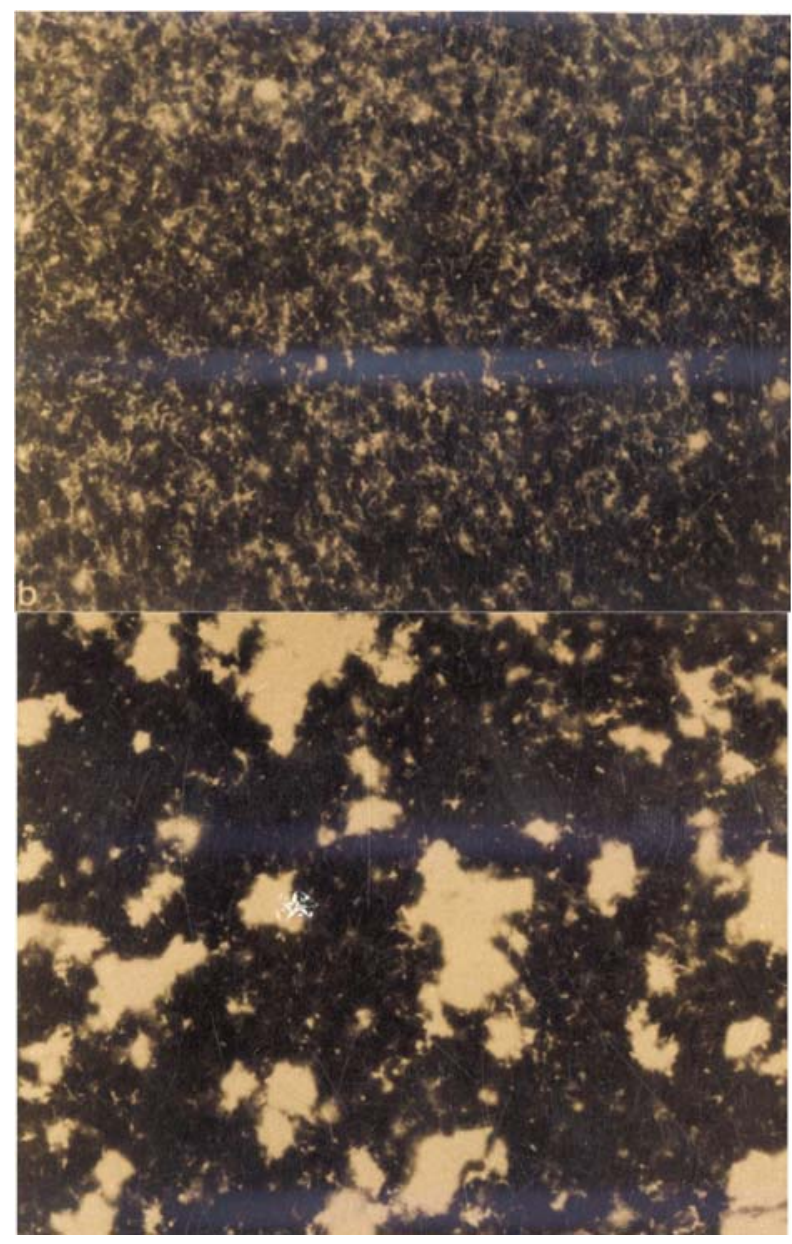

Fig. 4. MAT

(a) Test Negative: Free Leptospires - No clumps.

(b) Test Positive: Agglutinated leptospires (Clumps)

Enzyme Linked Immunosorbent Assay (ELISA) (Serion): ELISA for leptospirosis to detect IgM in specific, which indicates current infection. IgM ELISA was performed to 28 MAT positive samples and control. Here, Antigen coated microtitre plates were used [10].

Procedure: The patient's serum was diluted to a 1/100 with buffer (provided with kit). The diluted serum was loaded in respectively antigen coasted wells and incubated for 60 mins at $37^{\circ} \mathrm{C}$, in moist chamber. The washing buffer comprising phosphate buffered saline with $0.05 \%$ Twin 20 was diluted $1 / 30$ with freshly prepared water. The incubated plates were washed for minimum four times with intermittent drying on paper towels. Addition of conjugate containing Anti-human IgM alkaline phosphates was effected and the plates were incubated for 30 mins at $37^{\circ} \mathrm{C}$. The plates were washed again for four times and a final 30 mins incubation with substrate containing paranitrophenyl phosphate was effected. The reaction was stopped by addition of stopping solution (IM phosphoric acid) and the 
plates read at $405 \mathrm{~nm}$. The results are interpreted with simple calculations on reference to the standard chart provided. The O.D value on reference; if crosses $20 \mathrm{U} / \mathrm{ml}$ was found to be positive and below $15 \mathrm{U} / \mathrm{ml}$ was negative and those that fall in the range between $15-20 \mathrm{U} / \mathrm{ml}$ is a borderline case.

\section{RESULTS}

A total 165 samples were collected from high risk group of poultry and cattle workers with myalgia, diarrhoea, conjunctival suffusion, fever and jaundice. Out of which 17 were paired sera from patient and 10 were negative control. The sample were processed in Leptospira laboratory and screened for incidence of leptospirosis. The case history of the patients was recorded in a special pro forma. The results which we have attained by different tests and data were tabulated $(1,2,3 \& 4)$.

Table 1. Showing role of various tests in diagnosis of leptospirosis in our study

\begin{tabular}{|c|c|c|}
\hline Tests & $\begin{array}{l}\text { No. of Sample Positive I } \\
\text { Total No. of sample tested }\end{array}$ & $\%$ \\
\hline $\begin{array}{l}\text {-Microscopy } \\
\text { (DGI) }\end{array}$ & $06 / 165$ & 3.6 \\
\hline -Culture & $05 / 23$ & 8.6 \\
\hline -Serology & & \\
\hline${ }^{*} \mathrm{MSAT}$ & $31 / 165$ & 18.7 \\
\hline *MAT & $29 / 31$ & 93.5 \\
\hline $\begin{array}{l}{ }^{*} \text { ELISA } \\
(\lg \mathrm{M})\end{array}$ & $12 / 29$ & 41.3 \\
\hline
\end{tabular}

Cultural and isolation results: Attempts were made to isolate leptospire from 23 of the 165 blood specimen sent to the laboratory with a request for leptospiral agglutination test. Presumably these samples were from patients in whom the clinicians considered leptospirosis was a possible diagnosis. Among these leptospire were isolated from 5 blood sample cultures are usually performed with blood sample collected during 10th day of illness. But is does not contribute to an early diagnosis of disease. In this study culture in EMJH medium was attempted 23 sample but successes rate is very low (3 samples). The low isolation rate in the study could probably due to treatment received by the patients before sample collection. Organism which grown in the medium was stained with Fontana staining to view clear morphology.
Table 2. MAT - Titres Servoar

\begin{tabular}{|c|c|c|c|c|c|c|c|c|}
\hline \multirow[b]{2}{*}{ Serovar } & \multicolumn{7}{|c|}{ Titres } & \multirow[b]{2}{*}{$\begin{array}{c}\text { Total } / \\
\%\end{array}$} \\
\hline & 20 & 40 & 80 & 160 & 320 & 640 & $\begin{array}{l}128 \\
0\end{array}$ & \\
\hline \multirow{2}{*}{$\begin{array}{l}\text { Autumnalis } \\
\text { Hebdomadi }\end{array}$} & - & 2 & 1 & 4 & 1 & - & - & $8(25.5)$ \\
\hline & - & 1 & 2 & 2 & 1 & 1 & - & $7(22.5)$ \\
\hline \multirow{3}{*}{$\begin{array}{l}\text { s } \\
\text { Australis } \\
\text { pomona } \\
\text { Grippotyph }\end{array}$} & - & 1 & 2 & 2 & 1 & - & - & $6(19.5)$ \\
\hline & - & 1 & 1 & 1 & - & - & - & $3(9.6)$ \\
\hline & - & 1 & 0 & 1 & - & - & - & $2(6.5)$ \\
\hline \multirow{2}{*}{$\begin{array}{l}\text { Copenhage } \\
n i \\
\text { Mixed }\end{array}$} & - & & 1 & 1 & - & - & 1 & $3(9.6)$ \\
\hline & - & 1 & 1 & - & - & - & - & $2(6.5)$ \\
\hline Total & 0 & 7 & 8 & 11 & 3 & 1 & 1 & $\begin{array}{l}31 \\
(100)\end{array}$ \\
\hline
\end{tabular}

\begin{tabular}{|c|l|c|c|c|}
\hline $\begin{array}{c}\text { S.N } \\
\mathbf{0}\end{array}$ & Sex \&Age & $\begin{array}{c}\text { Total no. } \\
\text { of sample } \\
\text { analyzed }\end{array}$ & $\begin{array}{c}\text { No. of } \\
\text { sample } \\
\text { positive }\end{array}$ & $\begin{array}{c}\text { Percenta } \\
\text { ge }\end{array}$ \\
\hline 1. & $\begin{array}{l}\text { Male (20 to } \\
\text { 45) }\end{array}$ & 75 & 18 & 24.0 \\
\hline 2. & $\begin{array}{l}\text { Female(20t } \\
\text { 0 45) }\end{array}$ & 51 & 8 & 15.5 \\
\hline 3. & $\begin{array}{l}\text { Child and } \\
\text { teenage }\end{array}$ & 39 & 5 & 13.0 \\
\hline
\end{tabular}

Serological Results: Seroprevalance of leptospirosis was determined to be $18.7 \%$ with MSAT \& MAT. Positive serum sample had antibodies agent autumnalis, Hebdomadis, Javanica, Pomona, grippotyphosa, Icterohaemorrhagiae (the positive titre varied from 1: 40 to 1: 1280). Of the 31 MAT positive serum sample, 8 (25.8) were positive against serovar autumnalis, 7 (22.5) were positive against Serovar hebdomadis, 6 (19.5) were positive against Serovar australis, 3 (9.6) were positive against Serovar Pomona, 2(6.5) were positive against Serovar grippotyphosa, 3(9.6) were positive against Serovar copenhageni.

Of the 31 MAT serum samples subjected to IgM ELISA to determined status of infection. ELISA gave 22 positive current infective cases. The positive rate among deferent age group and sex also determined. Furthermore 5 or the 31 positive serum sample was positive for the age group between 5-20 years old, 18 were positive for the age group of 20-45 in male and 8 we positive for the same age group of female. 


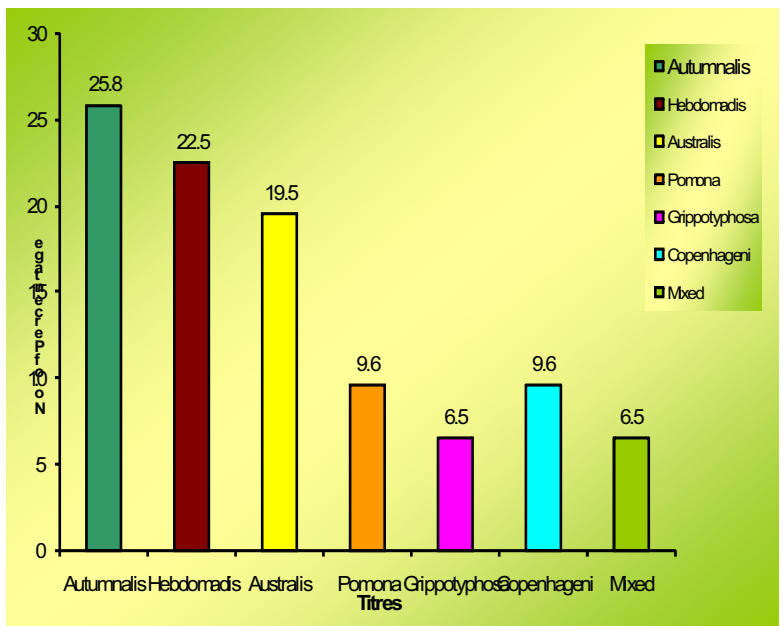

Fig. 5. Percentage of different Serovar findings in clinical specimens.

Table 3. Incidence of Leptospirosis in Relation to age and sex

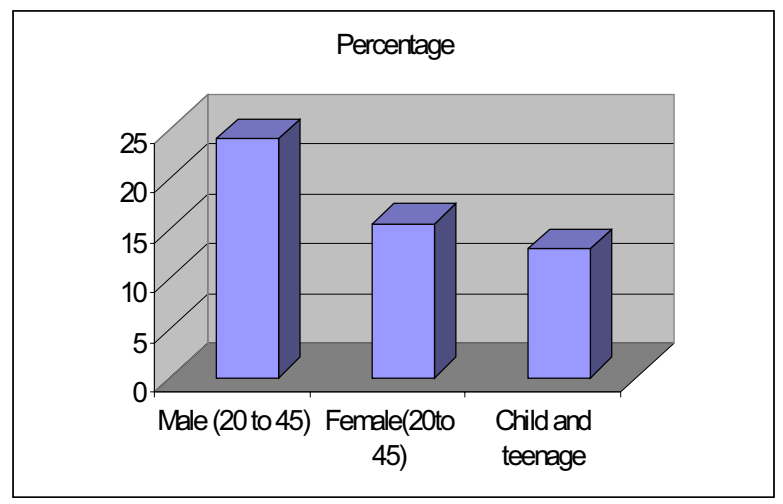

Fig.6 Incidence of Leptospirosis in Relation to age and sex

\section{DISCUSSION AND CONCLUSION}

In the present study, the seroprevalance of leptospirosis in cattle and poultry workers was determined to be

Table 4. Clinical Features in Leptospirosis Cases

\begin{tabular}{|c|l|c|c|}
\hline $\begin{array}{c}\text { Total no. of } \\
\text { leptospirosis } \\
\text { positive } \\
\text { cases }\end{array}$ & Symptoms & $\begin{array}{c}\text { No of } \\
\text { patients }\end{array}$ & Percentage \\
\hline \multirow{5}{*}{31} & Fever & 11 & 39.00 \\
\cline { 2 - 4 } & $\begin{array}{l}\text { Fever/ } \\
\text { Myalgia }\end{array}$ & 09 & 32.00 \\
\cline { 2 - 4 } & $\begin{array}{l}\text { Fever/ } \\
\text { jaundice }\end{array}$ & 05 & 18.00 \\
\cline { 2 - 4 } & $\begin{array}{l}\text { Diarrhea/ } \\
\text { Myalgia }\end{array}$ & 04 & 14.00 \\
\cline { 2 - 4 } & $\begin{array}{l}\text { Suconjunctival } \\
\text { hemorrhage }\end{array}$ & 02 & 7.00 \\
\hline \multicolumn{2}{|c|}{ Total } & 31 & 100.00 \\
\hline
\end{tabular}

$18.7 \%$ with MAT \& MSAT. According to the report of Koteswaran [11], seroprevalance of leptospirosis in human samples was found to be $57.5 \%$ during $1998-99$ and lower 32.8 in 2002-2003 and $10 \%$ in 2005-06 in Tamil Nadu However the result more (or) less similar to the report of sumathi et al [12]. So over results clearly shows thrincreased awareness about the disease in public. Earlier studies showed the seroprevalance of leptospirosis among urban population included $33.9 \%$ in Madurai of people of different occupations, $24.8 \%$ among conservancy workers in Cumbum and Bodi. But it is noTable- that the seroprevalance among industrial workers of Madurai City was low $8.7 \%$.

Attempt to identify (DGI) and isolates leptospires in EMJH medium mostly failed except 2 specimens. Analysis revealed that, with one possible exception, most of the specimen collected in second and third week of illness. Wolff ('1954) and Babudieri (1961) both concluded that isolations from blood specimens could nearly always be obtained during the first four days of illness, but rarely after the seventh or eight day. In some cases we can found leptospires in specimens by DGI but it failed to grow in supplied medium. It shows the patients received the treatments just before sample collection or immune development. IgM ELISA is the test of choice for diagnosis of current infection. The test detects genus specific IgM antibodies, which tend to become positive early in the disease (5 day)[13] . Present study showed $41.3 \%$ of current infection in the sample where the MAT titre was around 1:40, because IgM appear in early stage of infection. Hence Ig M ELISA is superior in diagnosis of current infection [14].

In these studies autumnalis was the most frequent Serovar found by MAT and it is followed by hebdomadis, australis, pomana, grippotyphosa, copenhageni. The higher prevalence of autumnalis and australis found in the study could be had close contact with the reservoir of these serovars (cattle and poultry) and it also found in contaminated water [15]. The clinical futures found in the study was fever (39\%), fever with Myalgia (32\%). Fever with jaundice (18\%), diarrhea with Myalgia (14\%) and subcongunctivel suffusion (7\%). sero positivity as higher in male $(24 \%)$ then in female (15.5\%).

In this study, it was concluded that prevalence of leptospirosis in cattle and poultry workers is more in Chennai. However, further studies should be performed to understand the epidemiology of leptospirosis in farm animals and it is association with human leptospirosis. Further more, some drawbacks of the serological tests could be overcome using molecular techniques like PCR and RAPD. 


\section{ACKNOWLEDGEMENT}

We are indebted to Sastha Educational Trust, HOD Colleagues for very capable technical assistance.

\section{REFERENCES}

[1] Ratnam, S., Subramaniyan, S., Madanagopalan, N., Sundaraj, T.S., Yayanthi.V. 1983, Isolation leptospires and demonstration of antibodies in human leptospirosis in Madras, India. Trans.Roy.Soc.Med.Hyg. 77, 455-458.

[2] Ratnam, C.O.R., Alex, J.C., Suresh, B., Muthusethupathi, M.A., and Helanmanuals, P.S. 1993, Leptospiral antibodies among human beings in Tamil Nadu. Ind.j.Med.Micro., 11,203-205.

[3] Kalimuthu Natrasasrinivasan, Nagarajan prabhu and Krishnaswamy slvanayagi, 2004, Jpn.j.Infeci. Dis.53, 193-197)

[4] Muthusethupathi, M.A. and Shivakumar, S. 1987, Acute renal failure due to Leptospirosis. J.Assoc. Physic.India. 35,631-633.

[5] Johnson \& Harris 1967, Differentiation pathogenic and saprophytic leptospires growth at low temperature. J. Bact., 94, 27-31.

[6] Faine, S. 1982, Guidelines for the control of leptospirosis. W.H.O. Offset Publication, 67, Geneva.

[7] Alston J.M and J.CBroom, 1958, Leptospirosis in man and animals. E \& S. Livingstone, Edinburgh, U.K

[8] Turner, 1968, Leptospirosis II, serology. Trans.R.Soc.Trop.Med.Hy g. 62:880-889.

[9] Sulzer and Jones, 1987, Leptospirosis methods in laboratory diagnosis V.S. Department of Health Education and Welfare CDC. Atlanta, USA.
[10] Wilson T.S. 1966, Recent observation on leptospirosis in Northern Ireland and their on current diagnostic methods. J.Cli.Path. 19, 415.

[11] Koteswaran A, 2006, seroprevalance of leptospirosis in man and animals in Tamil Nadu. In.J.M.MB.24, 329-330.

[12] Sumathi G, Pradeep KS, et al. 1995, Serodiagnosis of leptospirosis: A Madras study. Indi. J Medi Micro: 13: $192-5$

[13] Cousins, D.V. et al, 1983, The use of the enzymelinked immunosorbent assay (ELISA) to detect the $\lg M$ and $\lg G$ antibody response to Leptospira interrogans serovars hardjo, Pomona, and tarassovi in cattle. Vet. Microbial. 1983; 10: 439-450.

[14] Terpstra et al, 1980, Serodiagnosis of human leptospirosis by ELISA. Zbl. Bakt. Hyg. Adt. Orig., 247, 400-55.

[15] Terpatra, 1985, ELISAfor the detection of specific $\lg \mathrm{M}$ and $\lg \mathrm{G}$ in human leptospirosis. J. G. Microbial., 131, 377-85.

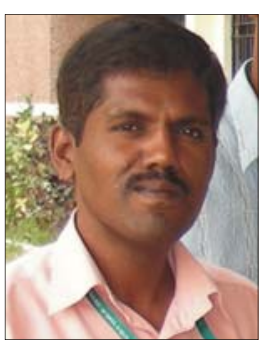

Mr. Thiruvengadam S. has specialized in Medical microbiology and has presented more than 10 research papers in National and International conference to his credit. $\mathrm{He}$ is currently working as a Senior Lecturer in Dept. of Biotechnology, Sree Sastha Institute of Engineering and Technology, Chennai. He has 9 years teaching experience and Persuing research in leptospirosis 